\title{
RESEARCH NOTE \\ Prevalence of the tracheal mite Acarapis woodi (Rennie) in Chile
}

\author{
Naomi Durán, Patricia Henríquez-Piskulich, and Patricia Aldea \\ Universidad Mayor, Centro de Estudios Apícolas (CEAPIMAYOR). Camino La Pirámide 5750, \\ Huechuraba, Santiago. Región Metropolitana, Chile.
}

\begin{abstract}
N. Durán, P. Henríquez-Piskulich, and P.Aldea. 2019. Prevalence of tracheal mites Acarapis woodi (Rennie) in Chile. Cien. Inv. Agr. 46(3): 295-301. Tracheal acariosis in Apis mellifera (honey bee) is caused by the endoparasitic mite Acarapis woodi and affects the respiratory system. This disease has received very little empirical attention in Chile. Its prevalence is unknown, as is whether its prevalence varies during different times of the year. The objective of the present study was to determine the frequency of $A$. woodi and to estimate whether there is variation in its expression among beekeeping seasons. A total of 1,408 hives were sampled between 2012 and 2016. The results showed that the average prevalence in the country was $10.1 \%$, with prevalences of $12.2 \%$ and $5.3 \%$ in the productive season and nonproductive season, respectively. A higher prevalence of tracheal acariosis was detected in the productive season. This study was the first to examine the prevalence of this disease in Chile. These findings provide insight into the prevalence of the disease in the Chilean context and can help to advance decisions about sanitary beehive management in the future.
\end{abstract}

Keywords: Acarapis, Apis mellifera, bee parasites, Chilean beekeeping, health, mite.

\section{Introduction}

A colony of honey bees, Apis mellifera, is host to a large number and variety of pest organisms. The pest organisms include vertebrates as well as obligate parasites such as the Tarsonemid and the microscopic mite Acarapis woodi (Rennie) (Acari: Tarsonemidae), which is also known as the tracheal mite (Sammataro et al., 2013). The latter pest is the agent of tracheal acariosis (Llorente, 2003). The prevalence of this endoparasite worldwide is unclear. However, in Latin America, Maggi et al., 2016 identified its presence by reviewing the

Received Jun 25, 2018. Accepted Aug 28, 2019. Corresponding author: patricia.aldea@mayor.cl health status of the bees in different countries and reported prevalences of $1-2.7 \%$ in Uruguay and $2.7 \%$ in the state of Tachira in Venezuela, but the prevalence at the country level is unknown. In Brazil, there are currently no official or scientific data about the prevalence of the mites (Maggi et al., 2016). In 2017, in different provinces of Argentina, the prevalence was $0 \%$ in winter (Szawarski et al., 2017).

This agent was first reported in Chile in 1962 (Maggi et al., 2016). However, it was only at the end of 2001 that reports of the disease were confirmed in apiaries in the Valparaíso Region by the Agricultural and Livestock Service (SAG) (Campano, 2004). The current records that exist 
in our country indicate that the prevalence of this parasite in the metropolitan region and at the national level in 2011 were approximately $12 \%$ and $10 \%$, respectively (Neira, 2012). However, "unofficial" records have also suggested that other geographical areas in Chile would exceed the national average, indicating that some areas have up to $20 \%$ prevalence among apiaries managed by nonprofessional beekeepers (unpublished data).

It is well documented in the literature that beekeepers usually do not perform the diagnosis of this endoparasite (Maggi et al., 2016). The reason for this is that diagnosis requires scientific qualifications and because it is a laborious and complex process (Sammataro et al., 2013) involving molecular techniques that require large numbers of bees, such as polymerase chain reaction (PCR) (Sammataro et al., 2013; Delmiglio et al., 2015) or involving enzymatic techniques such as enzyme-linked immunosorbent assay (ELISA), which have also been show effectiveness as a diagnoses method (Sammataro et al., 2013).

The mite lives and reproduces mainly in the prothoracic trachea of the adult bee (McMullan and Brown, 2005), which it perforates to feed on the hemolymph of its host (Bowman et al., 2004). The disease produces a nonspecific clinical symptomatology associated with the existence of thermoregulation problems in hives during the winter (Bowman et al., 2004; Villa and Danka, 2005). It is possible to see sick workers crawling near hives, with or without dislocated wings because of necrosis in the thoracic muscles; some can be observed to exhibit abdominal distention (Sammataro et al., 2013). The mortality rates are highest in winter, when the number of deaths peaks and subsequently falls to lower levels of death in summer (Llorente, 2003). On the other hand, hives parasitized with the mite Varroa destructor (the main pest affecting all beekeeping operations) also add to the high mortality rate in the winter period, making the losses greater (Garrido-Bailón et al., 2012).
It is estimated that the low overall prevalence of tracheal acariosis is a result of the frequent application of acaricidal treatments for control. For this reason, the mite $A$. wood $i$ was considered to be almost eradicated in countries such as Spain for many years (Garrido-Bailón et al., 2012). Although there are no reliable studies on the efficacy of existing acaricidal treatments, it appears that these treatments are effective enough to prevent clinical outbreaks of the disease (Garrido-Bailón et al., 2012). According to Martínez et al., (2016), specialists have attributed the zero prevalence of acariosis in the eastern region of Mexico to the application of formic acid treatments against $V$. destructor, which indirectly control the $A$. woodi mite. Maeda and Sakamoto (2016) used 30 grams of l-menthol for one month periods in different seasons on Apis cerana japonica to corroborate the effects of this organic acid on the mite. The authors found that the initial prevalence was affected after the treatment in the wintering season and that there was a positive correlation between the efficacy of the menthol treatment and the period of the year in which it was applied. Importantly, one of the synthetic products used against $V$. destructor is amitraz, which is an acaricide used in vertebrates (Sammataro et al., 2013). However, despite this last observation, the challenges in the health of Chilean hives are mainly due to i) the poor and late-in-the-season treatment of parasitic mites (Araneda and Calzadilla, 2011; Aldea et al., 2013), ii) the late detection of pathogens, iii) the limited access to adequate sanitary products and iv) the misuse of synthetic acaricides (Araneda and Calzadilla, 2011; Aldea et al., 2013). This last point is relevant to the Chilean context given that there has been little availability of registered products for apicultural use for several years. In fact, the only available products have been synthetic acaricides, such as flumethrin, and only a few registered organic products (thymol and other organic oils) along with other nonformal presentations of organic oils and acids (SAG, 2017). Despite the availability of these products, they have been useless against tracheal mites. Although the study of the effects of $A$. woodi on 
bee health has been neglected due to the presence of $V$. destructor on A. mellifera hives, the disease is still occurring worldwide (Maggi et al., 2016). Consequently, there is an overall underestimation of the negative impact of this disease on professional beekeeping, which adds to the impetus to study its prevalence in the Chilean context.

We hypothesized that the prevalence of tracheal acariosis in Chile between 2012 and 2016 would be higher than the last prevalence recorded in the country in 2011. We also expected that the prevalence of the disease would be higher in the nonproductive period than in the productive period.

The present study aimed to determine the prevalence of $A$. wood $i$ in Chile and whether there were differences in prevalence between the productive and nonproductive beekeeping periods.

\section{Materials and Methods}

\section{Sampling}

Apiaries: A total of 298 apiaries were sampled from sites that were distributed from the Arica and Parinacota Region ( $7^{\circ} 30^{\prime}$ to $21^{\circ} 28^{\prime}$ south latitude) to the Los Lagos Region ( $39^{\circ} 16^{\prime}$ and $44^{\circ} 04^{\prime}$ south latitude).

A total of 1408 samples were taken, with 973 during the productive beekeeping period (OctoberMarch) and 435 during the nonproductive period (April-September). Samples were taken according to availability and were not repeated, and their distribution was determined by the number of beekeepers who allowed us to carry out this study. The sampling was performed in the Langstroth hives of professional beekeepers and hobbyists. All samples were processed in the laboratory of the Apicultural Studies Center, CEAPIMAYOR, Universidad Mayor. The sampling was carried out in northern, central and southern Chile between 2012 and 2016 during the productive and nonproductive beekeeping periods. It is important to note that, unfortunately, in 2013 , no samples were obtained to determine the presence of the pathogen due to the lack of interest of the beekeepers in monitoring it. Accordingly, samples were obtained for the years 2012, 2014, 2015 and 2016. The samples were collected in a total of 298 apiaries. The collected samples corresponded to $10 \%$ of the beehives of the apiary, with a minimum of 5 samples per apiary. Each sample contained a minimum of 200 adult bees that were extracted from the brood chambers of three different frames. The samples were frozen to preserve them for further processing and analysis.

\section{Detection of $A$. woodi}

Diagnostic processing consisted of using the direct diagnostic methods for tracheal acariosis according to the protocol recommended by OIE (2008). First, fifty bees were extracted from the samples, and the first thoracic segment of each bee was cut with a scalpel. The segments were soaked in $5 \mathrm{ml}$ of lactic acid and heated at $60{ }^{\circ} \mathrm{C}$ for 5 minutes. The processed sample was observed under a magnifying glass at $4 \mathrm{X}$ magnification to observe the tracheal passage of each bee. A sample was diagnosed as positive if at least one egg or an immature or adult stage mite were found in the trachea. The results were tabulated considering the number of total samples and results per apiary, as well as the period of sampling.

\section{Data analysis}

The samples were classified as positive or negative after the diagnosis. All statistical analyses were computed with the IBM SPSS Statistics version 23 software (IBM SPSS, 2014). Descriptive statistics were used to obtain the prevalence of tracheal acariosis per period in Chile. Moreover, a chi-square test of independence was conducted to determine if there were significant differences in the prevalence between the productive and nonproductive periods in the Chilean colonies, 
allowing the nonparametric analysis of the categorical data. This analysis was appropriate for the present study given the unequal sampling between the periods in the present study.

\section{Results}

Of the 298 apiaries sampled in Chile between 2012 and 2016, only $1.68 \%$ tested positive for tracheal acariosis, and the remaining $98.32 \%$ were negative.

In terms of the data based on the number of hives sampled, the results showed that $10.1 \%$ of the 1408 hives between the years 2012 and 2016 were positive for the tracheal mites, and the remaining $89.9 \%$ of the hives were negative.

The prevalence of tracheal acariosis for the years 2012, 2014 and 2015 was $15.4 \%, 20.8 \%$ and $8.3 \%$, respectively. In 2016, the prevalence of tracheal acariosis was $1.6 \%$ (Figure 1).

Of the total number of hives sampled between 2012 and 2016, 5.3\% and $12.2 \%$ presented cases of acariosis in the nonproductive period and productive period, respectively. In this case, the chi-square test was valid, and the Fisher's exact test statistic showed significant values $\left(\chi^{2}=15.979\right.$, $\mathrm{p}<0.05)$. Therefore, there was a significant difference in the prevalence of the parasite between sampling periods, confirming the existence of a higher percentage of hives that were positive for acariosis during the productive period (Table 1).

\section{Discussion}

The prevalence values of $A$. woodi in the other Latin American countries are lower compared to those shown by the results of the present study in the Chilean context. In Argentina, the prevalence is $4.2 \%$ in winter; in Uruguay, between $1-2.7 \%$; and in Venezuela, 2.7\%. A study by Neira (2012) concluded that the prevalence at the national level in Chile was close to $10 \%$. However, there were limitations to the study when considering the sample size $(n=40)$, and there was still a question regarding the situation in our country. These investigations indicated that the level of tracheal acariosis was higher in Chile than in neighboring countries. Therefore, it is critical that future studies focus on the occurrence of this disease in Chile. This information would also help to understand the economic impact that the disease has on Chilean beekeeping and what sanitary programs must be created in the future.

Several empirical studies have shown that the prevalence of tracheal acariosis is significantly higher in winter than in summer (Llorente, 2003). However, our results showed a lower prevalence in the wintering season (nonproductive period)

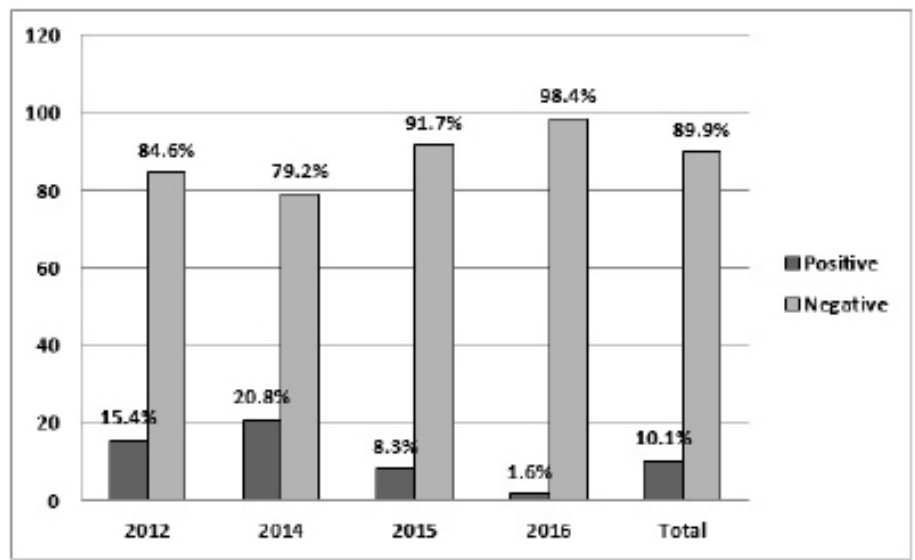

Figure 1. Prevalence (\%) of the tracheal mite in Chilean colonies per year. 
Table 1. Chi-square test of independence for the prevalence of tracheal acariosis in the productive period and the nonproductive period.

\begin{tabular}{|c|c|c|c|c|c|}
\hline \multirow{2}{*}{$\begin{array}{l}\text { Results } \\
(-)\end{array}$} & & \multicolumn{2}{|c|}{ Acarapis woodi } & \multirow[b]{2}{*}{ Total } & \multirow[b]{2}{*}{ Chi-square } \\
\hline & & $(-)$ & $(+)$ & & \\
\hline \multicolumn{6}{|l|}{ Period } \\
\hline & & 412 & 23 & 435 & \multirow{9}{*}{$\begin{array}{c}\mathrm{p}<0.05 \\
\left(15.979^{\mathrm{a}}\right)\end{array}$} \\
\hline & $\begin{array}{l}\text { Nonproductive (April- } \\
\text { September), count }\end{array}$ & & & & \\
\hline & $\begin{array}{l}\text { Within wintering period, } \\
\text { percentage }\end{array}$ & $94.7 \%$ & $5.3 \%$ & $100.0 \%$ & \\
\hline & Productive (October- & 854 & 119 & 973 & \\
\hline & March), count & & & & \\
\hline & $\begin{array}{l}\text { Within honey season, } \\
\text { percentage }\end{array}$ & $87.8 \%$ & $12.2 \%$ & $100.0 \%$ & \\
\hline \multicolumn{5}{|l|}{ Total } & \\
\hline \multirow{2}{*}{\multicolumn{2}{|c|}{ Average count within periods, percentage }} & 1266 & 142 & 1408 & \\
\hline & & $89.9 \%$ & $10.1 \%$ & $100.0 \%$ & \\
\hline
\end{tabular}

$(+)$ : Positive samples

$(-)$ : Negative samples

and a higher prevalence in the productive period. This opposing finding could be explained by the fact that $70 \%$ of Chilean beekeepers use chemical treatments to control varroa mites between the months of May and July (nonproductive period), with amitraz as the most used product (unpublished data). Chemical treatments against the $V$. destructor mite are usually applied in apiaries at the national level (Araneda and Calzadilla, 2011; Neira et al., 2012). Therefore, this treatment could generate an indirect effect on the control of tracheal acariosis by controlling $V$. destructor (Garrido-Bailón et al., 2012). In addition, evidence suggests that some organic treatments against varroosis generate an effect similar to those of the other chemicals, which indicates an indirect effect on tracheal acariosis. The low prevalence of the tracheal mite in Chile in comparison to other diseases, such as nosemosis and varroosis $(90 \%$ prevalence for the latter), could be explained by the effectiveness of some of the treatments for $V$. destructor against A. woodi (Aldea et al., 2013; Maggi et al., 2016).

The poor control of this disease in Chile could be explained by the poor amount of commercial registered acaricides that can be used by Chilean beekeepers. In fact, there are only three drugs registered in Chile. However, such drugs are only useful for the treatment of $A$. woodi (SAG, 2017). This finding may also suggest that beekeepers often improvise treatments when their hives are positive for the tracheal mite. Therefore, without an appropriate and specific treatment used to adequately combat $A$. woodi, the disease evidently has a high prevalence in the country.

Since these parasitic mites reside within the tracheas, their detection requires specialized techniques, materials and capabilities. The entire process is extremely laborious and time consuming, making it impractical for beekeepers, unlike the diagnostic process for varroosis. A similar situation occurs with the molecular diagnostic technique for this disease, which is primarily used in the scientific field. These diagnostics require a high level of specialization and technology and are thus more expensive (Sammataro et al., 2013; Delmiglio et al., 2015). In Chile, there are approximately 10 institutions in the entire country that perform the direct diagnosis of the parasite, and to date, there are no institutions that have implemented and validated the PCR technique for their molecular diagnosis. This obstacle, along with the lack of knowledge from beekeepers about the disease, can lead to the underdiagnosis of tracheal acariosis. The consequence is poor sanitary management when the agent is present. This could further explain the finding in the present study that a higher prevalence of the disease was found during the productive period. During this period, Chilean beekeepers stop the 
application of acaricides against $V$. destructor due to the increase of nectar flow and the accumulation of honey inside the colony. Additionally, as previously mentioned, the prevalence of the disease has been shown to be higher in Chile than in other Latin American countries. It is also possible that some mortality from $A$. wood $i$ has been attributed solely to varroosis in other countries. However, in the present study of the Chilean context, the systematic testing and focus on the detection of A. woodi allowed us to specifically identify the prevalence of this disease.

It is important to keep in mind that there is an underdiagnosis of the disease at the national level; the subclinical symptomatology of the disease makes it difficult to recognize, and there is a lack of appropriate sanitary management in Chile (Bowman et al., 2004; Villa and Danka, 2005) and a lack of knowledge on the part of beekeepers and health authorities with respect to the agent.

Given the above, it is not surprising that in 2014, the Agricultural and Livestock Service reported three cases of $A$. woodi through passive surveillance of cases in Chile in its Annual Health Report. Therefore, it seems necessary to formulate an active surveillance program to monitor this parasite based on the observed prevalence (10.1\%, Table 1).
In summary, it is necessary to investigate and develop specific studies to improve the understanding and knowledge of the incidence of tracheal acariosis and its effect on the mortality rates of the bee population in Chile. It is also important to consider that colonies parasitized by both $V$. destructor and $A$. woodi would present higher mortality in winter than in summer (Garrido-Bailón et al., 2012). This situation makes it imperative to find specific treatments against this disease, in addition to generating proposals for a health management program that will help reduce the prevalence of tracheal acariosis in Chile.

The main conclusions are as follows. We confirmed our hypothesis related to the national prevalence of tracheal acariosis. We found a calculated prevalence of $10.1 \%$. However, our second hypothesis was contrary to what was expected, and we found a higher prevalence of this disease during the productive period (12.2\%) than during the nonproductive period (5.3\%); therefore, we rejected this hypothesis.

There is a need to formulate health plans and specific treatments against this mite since $A$. woodi, together with Varroa destructor, generates considerable damage to beekeeping operations.

\section{Resumen}

N. Durán, P. Henríquez-Piskulich, y P. Aldea. 2019. Prevalencia del ácaro de las tráqueas Acarapis woodi (Rennie) en Chile. Cien. Inv. Agr. 46(3): 295-301. La acariosis traqueal, producida por el ácaro endoparásito Acarapis woodi, afecta al sistema respiratorio de Apis mellifera. Es una enfermedad apícola muy poco estudiada en Chile, desconociéndose su prevalencia y si ésta varía durante los diferentes períodos del año. El objetivo del estudio fue determinar la prevalencia de $A$. woodi y estimar si existe una variación entre temporadas apícolas (período productivo y no productivo). Se muestrearon 1.408 colonias entre los años 2012 y 2016 . Se obtuvo que la prevalencia promedio en el país fue de $10,1 \%$, siendo de $12,2 \%$ y de 5,3\% para la temporada productiva y no productiva, respectivamente. Se obtuvo además que hubo un mayor porcentaje de colonias positivas a acariosis traqueal en el período productivo. Este es el primer estudio con antecedentes de las prevalencias de esta enfermedad a nivel nacional. Esto permite obtener antecedentes para la toma de decisiones de manejos sanitarios futuros de las colonias en Chile.

Palabras clave: Acarapis, ácaros, apicultura chilena, Apis mellifera, parásitos de abejas, salud. 


\section{References}

Aldea, P., R. Rodríguez, A. Olivares, M. Farfán, D. Riveros, F. Núñez, and L.Trivelli. 2013. Effect of ambient temperature and humidity conditions on the efficacy of organic treatments against Varroa destructor in different climatic zones of Chile. J. Agric. Sci. Technol. A3:474-483.

Araneda, X., and A. Calzadilla. 2011. Evaluación de dos modelos de pisos trampa para el control del ácaro Varroa destructor Oud. sobre la abeja Apis mellifera L. (In Spanish, with English abstract). Idesia. 29:99-104. doi: 10.4067/S071834292011000300015

Bowman, D., R. Carl, and M. Eberhard. 2004. Parasitología para veterinarios. Madrid, España: Elsevier. 77-78 pp.

Campano, S., editor. 2004. Encuentro Apícola Regional. Contribución a la Sustentabilidad de la Apicultura de la X Región Acaropisosis, Acariasis interna o Acariosis tráqueal de las abejas melíferas, Río Negro. 25 May. 2004 Rio Negro, Chile.

Delmiglio, C., Q. Hai Fan, S. George, L. Ward, G. Budge, A. Flynn, and L. Kumarasinghe. 2015. Development and evaluation of real-time-PCR assay for the detection of Acarapis woodi (tracheal mites) in Apis mellifera. Apidologie. 47:691-702. doi: 10.1007/s13592-015-0420-8.

Garrido-Bailón, E., C. Bartolomé, L. Prieto, C. Botías, A. Martínez, A. Meana, R. MartínHernández, and R. Higes. 2012. The prevalence of Acarapis woodi in Spanish honey bee (Apis mellifera) colonies. Experimental Parasitology. 132:530-6. doi: 10.1016/ j.exppara.2012.08.018

IBM SPSS. 2014. IBM SPSS Statistics 23. University of Chicago, UE.

Llorente, J. 2003. Principales enfermedades de las abejas. Madrid, España: McGRAW.

Maeda, T., and Y. Sakamoto. 2016. Field application of menthol for Japanese honey bees, Apis cerana japonica (Hymenoptera: Apidae), to control tracheal mites, Acarapis woodi (Acari: Tarsonemidae). Experimental and Applied Aca- rology. 70:299-308. doi: 10.1007/s10493-0160072-z.

Maggi, M., K. Antúnez, C. Invernizzi, P. Aldea, M. Vargas, P. Negri, C. Brasesco, D. De Jong, D. Message, E. Teixeira, J. Principal, C. Barrios, S. Ruffinengo, R. Rodríguez, and M. Eguaras. 2016. Honeybee Health in South America. Apidologie. 47:835-854. doi: 10.1007/s13 592-016-0445-7.

Martínez, M., J. Rosas, D. Prieto, A. Carmona, B. Peña, and F. Ávila. 2016. Presence of Varroa destructor, Nosema apis, and Acarapis woodi, in honey bee (Apis mellifera) of the east region in the State of Mexico. Abanico Veterinario. 6:30-38 doi: http://dx.doi.org/10.21929/abavet2016.62.3.

McMullan, B., and M. Brown. 2005. Brood pupation temperature affects the susceptibility of honeybees (Apis mellifera) to infestation by tracheal mites (Acarapis woodi). Apidologie. 36:97-105. doi: 10.1051/apido:2004073.

Neira, M., editor. 2012. $8^{\circ}$ Encuentro Nacional de Ciencia y tecnología Apícola. Incidencia y prevalencia de patologías en abejas adultas y crías en Chile, Santiago. 18-19 Jul. 2012. Universidad Mayor publishing. Santiago, Chile.

Sammataro, D., L. Guzman, S. George, R. Ochoa, and G. Otis. 2013. Standard methods for tracheal mite research. Journal of Apicultural Research.52:1-20. doi: 10.3896/IBRA.1.52.4.20

Servicio Agrícola y Ganadero. 2017. Medicamentos Veterinarios de uso Apícola Registrados en el SAG. Servicio Agrícola y Ganadero, Chile.

Szawarski, N., S. Quintana, E. Levy, M. Lucía, L. Abrahamovich, M. Porrini, C. Brasesco, P. Negri, G. Sarlo, M. Eguaras, and M. Maggi. 2017. Is Acarapis woodi mite currently infesting Apis mellifera colonies in Argentina?.Journal of Apicultural Research. 56:387-393. doi: 10.1080/00218839.2017.1339519

Villa, D., and G. Danka. 2005. Caste, sex and strain of honey bees (Apis mellifera) affect infestation with tracheal mites (Acarapis woodi). Experimental and applied acarology. 37:157-164. doi: 10.1007/s10493-005-2647-y. 